\title{
Accountability Studies in Religious Non-Profit Organizations: Possible Contextual and Application Gaps
}

\author{
Zubaidah Mohd Ali \\ Faculty of Economics, Business and Accountancy, Universiti Malaysia Sabah \\ Jalan UMS, 88400, Kota Kinabalu Sabah, Malaysia \\ E-mail: zubaidah.mohdali69@gmail.com \\ Rozaidy Mahadi (Corresponding author) \\ Faculty of Economics, Business and Accountancy, Universiti Malaysia Sabah \\ Jalan UMS, 88400, Kota Kinabalu Sabah, Malaysia \\ E-mail: zaidy@ums.edu.my
}

Received: July 5, $2021 \quad$ Accepted: Sep. 26, $2021 \quad$ Published: December 1, 2021

doi:10.5296/ajfa.v13i2.18945 URL: https://doi.org/10.5296/ajfa.v13i2.18945

\begin{abstract}
Having substantial accountability standards and practices is a vital practice to ensure the survival of Religious-Based Non-Profit Organisations (RNPOs). This is because the RNPOs are not only representing the religion's ideals but at the same time, there are also responsible for disseminating ethical massage and good values in the community. Since the RNPOs played a significant role in society, many studies have highlighted the need to explore more accountability issues involving RNPOs. Hence, this study aims to provide a taxonomical review of literature that examined RNPOs' accountability practices and subsequently, suggesting plausible contextual and application gaps for future research. In so doing, this study utilised van Helden and Nortcott's (2010) and Rozaidy, Siti Nabiha, Rasid, and Raman's (2017) taxonomical methods in categorising accountability studies in RNPOs. As a result, four main themes have been identified from 60 selected high-impact journal articles. The four themes are 1) examining the outcomes of corporate integrity and accountability practices; 2) evaluating the RNPOs' internal control practices; 3) idlentifying financial reporting disclosures practices among RNPOs; and 4) exploring the influence of leadership skills on RNPOs' accountability practices.
\end{abstract}

Keywords: Accountability, Religious Non-Profit Organisation, Transparency, Taxonomy 


\section{Introduction}

In general, accountability is defined as the internal and external duty that dictates an individual or organisation to be accountable for their activities, accept responsibility, and disclose the results in a transparency manner (Paiva \& Carvalho, 2018; Edwards and Hulme, 1996; Roberts and Scapens, 1985). In addition, the concept of accountability is normally associated with having good stewardship and adhering to common norms and rules of humanity (Yasmin et al., 2014). For example, from the Islamic perspective, accountability can be viewed as a broader concept consisting of vicegerency, trust, and responsibility (Haniffa and Hudaib, 2011) that is designed for Allah and its subjects (Basri et al., 2016). While Buddhist and Hindu societies showed the main mechanisms of accountability is consist of trust, aspiration, and loyalty (Jayasinghe and Soobaroyen, 2009). For the Christian, the implementation of the accountability model in managing churches is commonly referred to by having adequate financial management practices, such as having accounting personals to prepare financial reports.

Over the past decades, incorporating accountability practices (i.e., integrating good governance practices, sound financial management, adhere to high ethical standards) have become an increasingly important element in projecting virtuous images and values, particularly, when it involves Religious-Based Non-Profit Organizations (RNPOs) (Fang et al., 2019; Roslan et al., 2017; Atan et al., 2017; Jayasinghe \& Soobaroyen, 2009). RNPOs play a significant role in society, their contributions to the public welfares are highly important and at the same time contributing to the country's social-economic development. Since the main objective of a non-profit organisation is neither profit-making nor reaching financial growth, thus, there are many facets of perspectives of accountability practices of RNPOs are left to be explored.

Despite the RNPOs' status as a public frontier in fighting and championing human rights, there are many RNPOs that engaged with mismanagement of funds and fraudulent activities (Saat et al., 2013). As a result, more demand from the public for RNPOs to incorporate decent financial accountability practices in managing their funds. Thus, there is an urgency to explore various contextual and practical contexts of accountability perspectives involving RNPOS, and subsequently, it will provide better understanding and solutions for authorities in combatting accountability issues from reoccurring in the future. Therefore, this study aims to provide fresh avenues of accountability perspectives involving RNPOs through constructing taxonomical research themes from related journal articles, and then suggesting plausible research gaps for future study.

The taxonomy construction for this study was based on van Helden and Northcott's (2010) and Rozaidy et al., 2017 taxonomical methods of themes categorisation. In so doing, 60 journals articles were analysed and as a result, four themes of accountability studies in RNPOs were identified: 1) examining the outcomes of corporate integrity and accountability practices; 2) evaluating the RNPOs' internal control practices; 3) idlentifying financial reporting disclosures practices among RNPOs, and 4) exploring the influence of leadership skills towards RNPOs' accountability practices. The rest of the paper is structured as follows. 
It starts with a discussion on the methodological process of the study, including the explanation of the selection of academic journals and the classification procedures. Then, follow with an elaboration of key issues from the identified themes and ended with concluding remarks on the future research's suggestion drawn from the analysis of the identified themes.

\section{Research Method: Classifying Themes}

To identify the new segments of study and/or new areas of research in accountability perspectives, several steps are needed, it includes identify, analyse, and categorise the most common or popular themes of study (i.e., topics/subject/issues/subjects) connecting to accountability practices in RNPOs. To ensure the process of identification and categorisation of themes are infallible, this study follows van Helden and Northcott's (2010) and Rozaidy et al.'s (2017) taxonomical methods of themes categorisation.

The first step in categorising the themes begins by identifying the relevant journal articles that studied accountability practices in religious-based non-profit organisations. The selection of the journal articles was limited to articles that were published in high-impact international accounting, and management journals. As a result, 60 relevant journals articles were reviewed and 68 percent of the articles were published in top-tier (high impact/indexes) international journals, ranging from business, management, and accounting journals, such as Accounting, Auditing \& Accountability Journal (AAAJ); British Accounting Review (BAR); Critical Perspective on Accounting (CPA); Accounting, Organizations and Society (AOS); Accounting Historians Journal. Hence, the following are the four themes regarding accountability studies in RNPOs:

A. Examining the outcomes of corporate integrity and accountability practices.

B. Evaluating the RNPOs' internal control practices.

C. Identifying financial reporting disclosures practices among RNPOs.

D. Exploring the influence of leadership skills towards RNPOs' accountability practices.

\section{The Main Themes in Accountability Studies in RNPOs}

The journals were grouped based on the similarity of their research objectives. The analysis revealed that most of the articles are focused on theme A, then followed by theme B, C, and D. The details of each theme will be discussed in the next subsections.

\subsection{Theme A: Examining the Outcomes of Corporate Integrity and Accountability Practices}

Theme A refers to a study that focused on the outcomes of corporate integrity practices among RNPOs. Studies that employed theme A are mostly based on fraud cases involving the RNPOs over the past decades (see, Ali et al., 2020; Atan et al., 2017; Arshad et al., 2015; Givens, 2012, Jayasinghe and Soobaroyen, 2009 and Irvine, 2005). Based on the analysis, studies in this category mainly ventured on these three main areas of topics: (i) ethical cultures, (ii) organisational cultures, and (iii) whistleblowing perspectives. 
Studies in ethical culture (i) dispensed empirical supports to back up the premise that individual's religiosity ideal such as donating, volunteering, and helping others are beneficial in promoting prosocial behaviour or voluntary action at both institutional levels- i.e., individual, and organisational level (see, Chuto et al., 2020; Septianto et al., 2020; Jamal et al., 2019; Jayasinghe and Soobaroyen, 2009; Irvine, 2005; Grimalda and Sacconi, 2005). At the individual level, for instance, Jamal et. al. (2019) study revealed that Islamic beliefs and values, and altruistic attitudes motivate Muslim members in Islamic NGOs to involve in charity activities irrespective of religious background with peace and harmony as the focal points in mind. Meanwhile, at organisational level, Jayasinghe and Soobaroyen (2009) found that the accountability practices implementation is perceived by people as being ceremonial rituals aimed to strengthen the temple's righteous and prudent image to the religious society. In general, the previous study indicates that the ethical culture is the most important feature in the relationship between accountability and corporate integrity (Atan et al., 2007).

For organisational cultures (ii), a study in this category mainly discussed the influence of organisational cultures toward RNPOs' corporate integrity practices. Moreover, studies show that organisational culture is highly influenced by the RNPOs' effort in providing transparency in corporate practices, which is often practiced by the RNPOs with the underlying objective to maintain a good organisational image or strong work ethic (see, Slatten et al., 2020; Fang et al., 2019; Atan et al., 2017; Senses-Ozyurt, 2015; Givens, 2012). For example, Atan et al. (2017) revealed that organisation with the same values and beliefs will motivate employees to have better organisational performance, as well as a beneficial trait in attracting new volunteers.

Whistleblowing perspectives (iii) are the third common topic of study in corporate integrity and accountability practices among RNPOs. Studies in this context mainly focused on the urgency for RNPOs to adopt whistleblowing practices to enhance their integrity and to increase public confidence. Having sound whistleblowing practices will provide a diagnostic signal for fraudulent behaviours detection, and at the same time projecting a positive integrity image, which consequently increased the RNPOs' chances of acquiring more donations from existing and potential stakeholders (Ali et al., 2020). For instance, a study from Arshad et al. (2015) discussed the characteristics of whistleblowing that should be implemented by RNPOS in detecting inherent fraudulence behaviours and helping the RNPOs to minimize the negative impacts on the organization's survival.

\subsection{Theme B: Evaluating the RNPO's Internal Control Practices}

RNPOs are never shy from fraudulent cases, especially among small and medium RNPOs with poor internal control systems (Zainon et al., 2014; Arshad et al., 2015; Kamaruddin and Ramli, 2017; Atan et al., 2017). Contextually, most of the studies in this category are often emanated from Christian-based organisations (see, Tanui et al. 2016; Cornell et al. 2013; Ventura and Daniel, 2010; Budde, 2008; and Elson et al., 2007). Coverage on Christian-based NGOs' fraudulent cases is not a strange phenomenon, since there are many cases of sexual abuse scandals involving Catholic churches, and on top of that, some of those churches were also accused of embezzlement of funds and illegal leasing of church's properties (Tanui et al., 2016; Cornell et al., 2013; Budde, 2008; Bowrin, 2004). 
In addition, other studies in this category, such as Daff and Parker, 2020; Kamaruddin and Ramli, 2017; Tanui et al., 2016; Cornell et al, 2013; Saat et al., 2013; Budde, 2008; Elson et al., 2007 discussed the advantages of having effective internal controls practices and the importance of measuring RNPOs' performances through implementing performance measurement systems in the organisations (Gresakova, 2020; Moura et al., 2018; Sani et al., 2017; Arvidson and Lyon, 2014). However, studies that examined RNPOs' internal control practices in other main religions (such as Islam, Buddhism, Hinduism, etc.) are relatively scarce (Said et al., 2013; Lightbody, 2000; Elson et al., 2007; Bowrin, 2004). Thus, more studies are needed in this context (Kamaruddin and Ramli, 2017; Sani et all, 2017).

\subsection{Theme C: Identifying Financial Reporting Disclosure Practices among RNPOs}

Recently, more researchers have ventured into this category of study. This new trend has been motivated by numerous reported fraudulent cases involving RNPOs. Studies have revealed that lack of accountability practices, such as effective financial procedures, proper auditing systems, and good governance models have tarnished the RNPOs' reputation and consequently, more stakeholders are starting to question the RNPOs' ability in managing their resources (Sapingi et al., 2020; Paiva and Carvalho, 2018; Roslan et al., 2017; Zainon et al., 2014). Besides that, studies in this category also elaborate the advantage of having a high level of financial reporting disclosures in enticing more financial supports from RNPOs' stakeholders (Basri et al., 2016; Paiva and Carvalho, 2018; Ramli et al., 2018; Yasmin and Haniffa, 2015).

However, previous literature revealed that RNPOs are often being imposed or subjected to less stringent reporting requirements. This unfavourable rule affects the quality of reported information by the RNPOs since they are less pressured to provide transparent financial information (Roslan et al., 2017; Arshad et al., 2013). This situation happens because of inconsistent standards and guidelines in preparing financial reports for non-profit organisations (Sapingi et al., 2020, Roslan et al., 2017). As a result, RNPOs are often disclosing more administrative information rather than financial achievements. Although many studies have examined disclosure practices in various organizations, studies on financial guidelines and disclosures among RNPOs have been neglected (Yasmin et al., 2014). Thus, some authors suggest that more studies are needed, especially in examining financial reporting guidelines among RNPOs (Sapingi et al., 2020; Roslan et al., 2017; Yasmin and Haniffa, 2015; Yasmin et al., 2014; Radzi and Noor, 2012).

\subsection{Theme D: Exploring the Influence of Leadership Skills Towards RNPOs’ Accountability Practices}

The fourth theme is a study focused on the exploration of the effects of leadership skills on RNPOs' accountability practices. Study in the area is the least favourite theme in accountability studies among RNPOs (see Phipps et al., 2010; McMurray et al., 2009; Lightbody, 2000; Bartunek, 1984). Hence, studies on leadership in RNPOs gives a contextual and theoretical glimpse on the embedded motivations and challenges faced by the RNPOs, depending on their location, size, culture, and organisational and institutional structures (Ortiz-Gomez et al., 2020; Phipps et al., 2010; Geer et al., 2016; Arshad et al., 2018). 
the service of their teams, (ii) the mission, and (iii) act with justice (Ortiz-Gomez et al., 2020). The embeddedness of leaders' moral values positively affects organisational accountability, since leader plays a central role in promoting accountability values to its members (Geer et al., 2016; Sharip et al., 2019). For example, Atan et al. (2017), found that leadership indirectly influenced an organisation's accountability through the roles of leaders in encouraging accountability practices in the organisations. Moreover, other studies examined external qualities of good leadership such as communication skill capabilities in motivating their members to achieve organisational objectives (Mohd Sharip et al., 2019; Arshad et al., 2018; McMurray et al., 2010; Arshad et al., 2018; Ortiz-Gomez et al., 2020; Yaghi, 2008). Hence, the lack of studies in this category might be due to the nature of the study of this category that heavily relies on perception models rather than employing empirical case studies method that caused a lack of demands from academic readers for more studies to be done in this category.

\section{Conclusion Remarks}

Our taxonomical analysis shows that most of the literature on accountability studies in religious-based NGOs is mainly derived from Christian-based institutions, while there is still a lack of studies done from the perspective of other major religions including Islam, Buddhism, and Hindu. More studies in other religions are needed because accountability issues not only occur in Christian-based NGOs but also occurred in other religions. For instance, Sani et al. (2016) expressed the need to conduct more empirical research on Islamic-based NGOs since there is an uptrend in fraudulent cases involving Islamic-based non-profit organisations, which posed an extreme concern among Muslims towards the ability of Islamic-based NGOs to perform their due diligent in managing donations accountably. Thus, more research in this context provides a greater opportunity to explore RNPOs' accountability practices in different types of religions.

Moreover, despite the increasing studies on accountability practices among RNPOs in developed countries, there has been little study on the RNPOs in developing countries. This is because many developing countries have been associated with less stringent statutory requirements and low legal framework uniformity for good governance practices for their RNPOs to be followed (Paiva and Carvalho 2018; Ramli et al., 2018; Basri et al., 2016). For example, in Malaysia, studies showed a low compliance level of transparency due to the inconsistency in financial disclosure requirements for RNPOs (Sapingi et al., 2020; Yusop et al., 2020; Zainon and Wah, 2014; Arshad et al., 2013).

Besides that, for the future, comparative case studies between different types of non-profit organisations (i.e., religious, and non-religious-based NGOs) are highly meeded to provide a valuable understanding of the interplay issues between various types of non-profit organisations. More studies concerning the implementation of accountability practices in RNPOs are crucial to ensure more information about the transparency and efficiency in financial management can be scrutinised by both parties, the authorities, and the public (Arshad et al., 2013). 


\section{Acknowledgments}

The authors acknowledge the financial support from the Ministry of Higher Education of Malaysia under the FRGS fund (FRGS/1/2018/SS01/UMS/03/1) 'Developing Financial Integrity Assessment Model for Religious Nonprofit Organisations in Malaysia'. The authors also like to extend our thanks to all the organisations and its members for their willingness and participation in this study.

\section{References}

Ali, Z., Abdul-Kader, S. Z. S. \& Mohamad, N. A. (2020). Analysing the Need to Regulate Non-profit Foundations under the Trustees (Incorporation) Act 1952: Towards Transparency and Good Governance, International Journal of Business and Society, 21(1), 165-176.

Arshad, R., Razali, W. A. A. W. M. \& Bakar, N. A. (2015). Catch the "Warning Signals": The Fight against Fraud and Abuse in Non-Profit Organisations. Procedia Economics and Finance, 28, 114-120. https://doi.org/10.1016/S2212-5671(15)01089-8

Arshad, R., Abu Bakar, N., Sakri, F. H. \& Omar, N. (2013). Organizational Characteristics and Disclosure Practices of Non-profit Organizations in Malaysia, Asian Social Science, 9(1), 209-217. https://doi.org/10.5539/ass.v9n1p209

Arvidson, M., and Lyon, F. (2014). Social Impact Measurement and Non-profit Organizations: Compliance, Resistance, and Promotion. VOLUNTAS: International Journal of Voluntary and Nonprofit Organizations, 25(4), 869-886. https://doi.org/10.1007/s11266-0113-9373-6

Bartunek, J. M. (1984). Changing Interpretive Schemes and Organizational Restructuring: The Example of a Religious Order. Administrative Science Quarterly, 29(3), 357-372. https://doi.org/10.2307/2393029

Basri, H., Siti-Nabiha, A. K. \& Abd-Majid, M. S. (2016). Accounting and Accountability in Religious Organizations: A Islamic Contemporary Scholars' Perspective. Gadjah Mada International Journal of Business, 18(2), 207-230.https://doi.org/10.22146/gamaijb.12574

Bowrin, A. R. (2004). Internal Control in Trinidad and Tobago Religious Organizations. Accounting, Auditing \& Accountability Journal, 17(1), 21-152. https://doi.org/10.1108/09513570410525238

Budde, M. L. (2008). The Rational Shepherd: Corporate Practices and The Church. Studies in Christian Ethics, 21(1), 96-116. https://doi.org/10.1177/095394680808972.9

Chuto, P., Iwu, C. G and Tengeh, R. K. (2020). Non-Profit Organisations and Socio-Economic Development in South Africa: A literature Analysis. Humanities \& Social Sciences Reviews, 8(20), 589-600. https://doi.org/10.18510/hssr.2020.8267

Cornell, R. M., Johnson, C. B., \& Schwartz, W. C. (2013). Influence of Leadership Positions on Internal Controls and Reported Fraud in Religious Organizations. Journal of Forensic \& Investigative Accounting, 5(1), 85-115.

Edwards, M. \& Hulme, D. (1996). Too Close for Comfort? The Impact of Official Aid on 
Nongovernmental Organizations. World Development, 24(6), 961-973. https://doi.org/10.1016/0305-750X(96)00019-8

Elson, R. J., O'Callaghan, S. \& Walker, J. P. (2007). Corporate Governance in Religious Organizations: A Study of Current Practices in the Local Church. Academy of Accounting and Financial Studies Journal, 11, 97- 107.

Fang, Q., Fisher, K. R., \& Li, B. (2019). Follower or Challenger? How Chinese Non-governmental Organizations Manage Accountability Requirements from Funders. International Society Third-Sector Research, http://doi.org/10.1007/s11266-019-00184-7

Geer, B. W., Maher, J. K. \& Cole, M.T. (2008). Managing Nonprofit Organizations: The Importance of Transformational Leadership and Commitment to Operating Standards for Nonprofit Accountability. Public Performance \& Management Review, 32(1), 51-75. https://doi.org/10.2753/PMR1530-9576320103

Givens, R. J. (2012). The Study of the Relationship Between Organizational Culture and Organizational Performance in Non-Profit Religious Organizations. International Journal of $\begin{array}{llll}\text { Organization } \quad \text { Theory } \quad \text { B } & \text { 239-263. }\end{array}$ https://doi.org/10.1108/IJOTB-15-02-2012-B004

Gresakova, E. (2020). The Impact of Time Management on Finance if Slovak Non-Profit Organizations. 55th International Scientific Conference on Economic and Social Development.

Grimada, G. \& Sacconi, L. (2005). The Constitution of the Not-For-Profit Organisation: Receprocal Conformity to Morality. Constitutional Political Economy, 16(3), 249-279. https://doi.org/10.1007/s10602-005-2833-2

Haniffa, R. and Hudaib, A. (2011). Important of Religiosity Dimension in Strategic Management Accounting for TFIs, Journal of Islamic Accounting and Business Research.

Irvine, H. (2005). Balancing Money and Mission in a Local Church Budget, Accounting, Auditing \& Accountability Journal, 18(2), 211-237. https://doi.org/10.1108/09513570510588733

Jamal A., Yaccob A., Bartikowski B. \& Slater S. (2019). Motivations to Donate: Exploring the Role of Religiousness in Charitable Donations. Journal of Business Research, 103, 319-327. https://doi.org/10.1016/j.jbusres.2019.01.064

Jayasinghe, K., \& Soobaroyen, T. (2009). Religious "Spirit" and "Peoples' Perceptions of Accountability in Hindu and Buddhist Religious Organizations. Accounting, Auditing \& Accountability Journal, 22(7), 997-1028. https://doi.org/10.1108/09513570910987358

Kamaruddin, M. I. H. \& Ramli, N. M. (2017). A Case Study of Internal Control Practices in Islamic Non-Profit Organizations in Malaysia. Asian Journal of Accounting and Governance, 8, 13-25. https://doi.org/10.17576/AJAG-2017-08-02

Lightbody, M. (2000). Storing and Shielding: Financial Management Behaviour in a Church 


\section{Macrothink}

Asian Journal of Finance \& Accounting

ISSN 1946-052X

2021, Vol. 13, No. 2

Organization. Accounting, Auditing, \& Accountability Journal, 13(2), 156-174. https://doi.org/10.1108/09513570010323245

McMurray, A.J., Pirola-Merlo, A., Sarros, J.C. \& Islam, M.M. (2010). Leadership, climate, Psychological Capital, Commitment, and Wellbeing in Non-Profit Organization. Leadership \& Organization Development Journal, 31(5), 436-457. https://doi.org/10.1108/01437731011056452

Moura, L. F., de Lima, E. P., Deschamps, F., Van Aken, E., da Costa, S. E., Treinta, F. T. and Prado Cestari, J. M. (2019), Designing Performance Measurement Systems in Nonprofit and Public Administration Organization. International Journal of Productivity and Performance, 68(8), 1373-1410. https://doi.org/10.1108/IJPPM-06-2018-0236

Ortiz-Gomez, M., Molina-Sanchez, H., \& Ariza-Montes. (2020). Development and Validation of a Spanish Short Servant Leadership Survey among Spanish Workers in Religious Non-Profit Organizations. Sustainability, 12, 3766.

Paiva, I., \& Carvalho, L. (2018). Accounting and Management Practices in the Third Sector $\begin{array}{llll}\text { in Angola. Economics and } & \text { Sociology, }\end{array}$ https://doi.org/10.14254/2071-789X.2018/11-3/2

Phipps, K. A. \& Burbach, M. E., (2010). Strategic Leadership in the Nonprofit Sector: Opportunities for Research. Journal of Behavioral and Applied Management, 11(2), 137-155.

Radzi, S. H. M. \& Noor, R. M. (2012). Tax Reporting for Non-Profit Organizations (NPOs) in Malaysia. 2012 IEEE Symposium on Business, Engineering and Industrial Applications, Bandung, 62-67. https://doi.org/10.1109/ISBEIA.2012.6422965

Ramli, N. M., MdAli, N. S. A., \& Muhammed, N. A. (2018). Integrated Reporting Based on Maqasid Al-Shariah: A proposed Framework for Islamic Non-Profit Organzations. Advance in Economics, Business and Management Research, 57, 63-73. https://doi.org/10.2991/piceeba-18.2018.80

Roberts, J. \& Scapens R. (1985). Accounting Systems and Systems of Accountability Understanding Accounting Practices in their Organisational Contexts, Accounting. Organizations and Society, 10(4), 443-456.https://doi.org/10.1016/0361-3682(85)90005-4.

Roslan, N., Arshad, R., \& Pauzi, N. F. M. (2017). Accountability and Governance Reporting by Non-Profit Organizations, SHS Web of Conferences, 36, 00041. https://doi.org/10.1051/shsconf/20173600041

Saat, N. F., Mohamed, I. S., Zakaria, N. B. \& Omar, N. (2013). Factors Determining Level of Internal Controls Implementation Among Non Profit Organizations in Malaysia. Advance in Natural and Applied Science, 7(5), 425-434.

Said, J., Mohamed, A. Mohd-Sanusi, Z. \& Syed-Yusuf, S. N. (2013). Financial Management Practices in Religious Organizations: An Empirical Evidence of Mosque in Malaysia. International Business Research, 6(7), 111-119. https://doi.org/10.5539/ibr.v6n7p111 
Sani, A., Saidin, A., Bustaman S., Adanan A. \& Abd Samad K. (2017). Formulating a Performance Measurement System using Balanced Score Card in Islamic Philanthropy Institutions. SHS Web of Conferences, 36. https://doi.org/10.1051/shsconf/20173600023

Sapingi R., Nelson, S. P. \& Obid, S. N. S. (2020). Disclosure Practices and Efforts towards Proposing I-ZKDI: A Case of Malaysian Religious Non-Profit Organisation. International

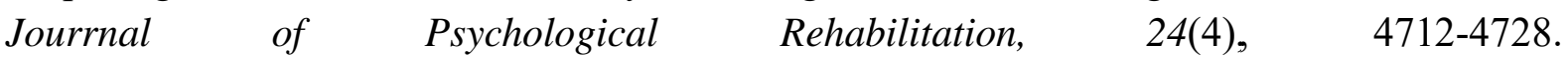
https://doi.org/10.37200/IJPR/V24I4/PR201571

Septianto, F., Tjiptono, F., Paramita, W. \& Chiew, T. M. (2020) The Interactive Effects of Religiosity and Recognition in Increasing Donation. European Journal of Marketing, 0309-0566. https://doi.org/10.1108/EJM-04-2019-0326

Sharip, S. M., Awang, M \& Ismail, R. (2019). onceptualizing the Impact of Leader-member Exchange in Non-Profit and Religious Organisations: The Case of Waqf Institutions in Malaysia. Journal of Emerging Economics \& Islamic Research, 7(3), 71-85. https://doi.org/10.24191/jeeir.v7i3.6197

Slatten, L. A., Bendickson, J. S., Diamond, M. \& McDowell, W. C. (2020), Staffing of Small Nonprofit Organizations: A Model for Retaining. https://doi.org/10.1016/j.jik.2020.10.003

Senses-Ozyurt, S. (2015). Political Institutional Environment and Management Culture as Determinants of Nongovernmental/ Nonprofit organizations' Performance. International Journal of Organization Theory and Behavior, 18(3), 269-303. https://doi.org/10.1108/IJOTB-18-03-2015-B001

Tanui, P. J., Omare, D. \& Bitange, J. B. (2016). Internal Control System for Financial Management in the Church: A Case of Protestant Churches in Eldoret Municipality, Kenya. European Journal of Accounting, Auditing and Finance Research, 4(6), 29-46.

Ventura M. \& Daniel S. J. (2010). Opportunities for Fraud and Embezzlement in Religious Organizations: An Exploratory Study. Journal of Forensic \& Investigative Accounting, 2(1), 1 35.

Yaghi, A. (2008). Leadership Values Influencing Decision-Making: An Examination of Nine Islamic, Hindu and Christian Nonprofit Institutions in the US, South Asian Journal of Management, 15, 24.

Yasmin, S. \& Haniffa, R. (2015). Accountability and Narrative Disclosure by Muslim Charity Organisations in the UK. Journal of Islamic Accounting and Business Research, 8(1), 70-86. https://doi.org/10.1108/JIABR-06-2015-0024

Yasmin, S., Haniffa, R., \& Hudaib, M. (2014), Communicated Accountability by Faith-Based Charity Organisations. Journal Business Ethics, 122, 103-123. https://doi.org/10.1007/s10551-013-1759-2

Yusop, R., Mahmud, R., Sabli, N. Awang, N. F. A. \& Ghazali, N. (2020). Sources of Funding for Private Tahfiz Institutions in Kuala Selangor. International Journal of Innovation, Creativity and Change, 10(12), 21-35. 
Zainon S., Atan R., Wah Y. B., Ahmad A., Othman M. A., \& Sau'dah N. (2014) An Integrated Ritual Effectiveness Accountability Reporting System (i-REARS) FOR Non-Profit Organizations. International Business Research, 7(5), 156-165.

\section{Main References for Taxonomy Methodology}

Helden, G. J. V., \& Northcott, D. (2010). Examining the Practical Relevance of Public Sector Management Accounting Research. Financial Accountability \& Management, 26(2), 213-241. https://doi.org/10.1111/j.1468-0408.2010.00499.x

Rozaidy, M., Siti-Nabiha, A. K., Rasid, M. \& Raman, N. (2017). Accrual Accounting in Public Sectors: Possible Contextual and Application Gaps for Future Research Agenda. Asian Journal of Finance \& Accounting, 9(1), 245-260. https://doi.org/10.5296/ajfa.v9i1.10968

\section{Appendix A}

\section{Classification included in this review and their classification}

Criterion - research objective:

A. Examining the outcomes of corporate integrity and accountability practices.

B. Evaluating the RNPOs' internal control practices.

C. Identifying financial reporting disclosures practices among RNPOs.

D. Exploring the influence of leadership skills towards RNPOs' accountability practices.

Table 1. Classification of Paper According to Research Objective

\begin{tabular}{|c|c|c|c|c|c|}
\hline $\mathrm{NO}$ & Authors and Title & $\mathbf{A}$ & B & $\mathbf{C}$ & $\mathbf{D}$ \\
\hline 1 & $\begin{array}{l}\text { Abdullah Sani A., Saidin A., Bustaman K. S., Adanan S. } \\
\text { A. \& Abd Samad K. (2017), Formulating a Performance } \\
\text { Measurement System Using Balanced Score Card in } \\
\text { Islamic Philanthropy Institutions }\end{array}$ & & / & & \\
\hline 2 & $\begin{array}{l}\text { Ali Z., Abdul-Kader S. Z. S. \& Mohamad N. A. (2020) } \\
\text { Analysing the Need to Regulate Non-profit Foundations } \\
\text { under the Trustees (Incorporation) Act 1952: Towards } \\
\text { Transparency and Good Governance }\end{array}$ & / & & & \\
\hline 3 & $\begin{array}{l}\text { Alshammari A. A., Rasli A., Alnajem M \& Arshad A. S. } \\
\text { (2014). An Exploratory Study on the Relationship } \\
\text { between Organizational Innovation and Performance of } \\
\text { Non-Profit Organizations in Saudi Arabia. }\end{array}$ & / & & & \\
\hline 4 & $\begin{array}{l}\text { Arshad R., Abu Bakar N., Sakri F. H. \& Omar N. (2013). } \\
\text { Organizational Characteristics and Disclosure Practices } \\
\text { of Non-profit Organizations in Malaysia }\end{array}$ & & & / & \\
\hline 5 & $\begin{array}{l}\text { Arshad R., Mahamud M. M., Rahmat N. E. \& Nair R. } \\
\text { (2018), Desired Board Capabilities for Good Governance } \\
\text { in Non-Profit Organizations }\end{array}$ & & & & / \\
\hline
\end{tabular}




\section{Macrothink}

Asian Journal of Finance \& Accounting

ISSN 1946-052X

2021, Vol. 13, No. 2

\begin{tabular}{|c|c|c|c|c|}
\hline 6 & $\begin{array}{l}\text { Arshad R., Razali W. A. A. W. M. \& Bakar N. A. } 2015 . \\
\text { Catch the "Warning Signals": The Fight against Fraud } \\
\text { and Abuse in Non-Profit Organisations. }\end{array}$ & 1 & & \\
\hline 7 & $\begin{array}{lll}\text { Arvidson M., and Lyon F. (2014) } & \text { Social Impact } \\
\text { Measurement and Non-profit } & \text { Organizations: } \\
\text { Compliance, Resistance, and Promotion. } & \end{array}$ & & & I \\
\hline 8 & $\begin{array}{l}\text { Atan R., Alam M. M \& Said J. 2017. Practices of } \\
\text { Corporate Integrity and Accountability of Non-Profit } \\
\text { Organizations in Malaysia. }\end{array}$ & I & & \\
\hline 9 & $\begin{array}{l}\text { Bartunek J. M. (1984). Changing Interpretive Schemes } \\
\text { and Organizational Restructuring: The Example of a } \\
\text { Religious Order }\end{array}$ & & I & \\
\hline 10 & $\begin{array}{l}\text { Basri H., Siti-Nabiha A. K. \& Abd-Majid M. S. (2016), } \\
\text { Accounting and Accountability in Religious } \\
\text { Organizations: A Islamic Contemporary Scholars' } \\
\text { Perspective }\end{array}$ & & & I \\
\hline 11 & $\begin{array}{l}\text { Bowrin A. R. (2004), Internal Control in Trinidad and } \\
\text { Tobago Religious Organizations }\end{array}$ & & I & \\
\hline 12 & $\begin{array}{l}\text { Budde M. L. (2008), The Rational Shepherd: Corporate } \\
\text { Practices and The Church. }\end{array}$ & & I & \\
\hline 13 & $\begin{array}{l}\text { Cerda-Suarez L.M., Valero-Matas J. A., } \\
\text { Jaramillo-Cardona M. C. \& Ramirez M. R. (2020) } \\
\text { Managing Cross-Border Conflicts Through Volunteer } \\
\text { Commitment: A Religious and Non-profit Organizations } \\
\text { in the San Diego-Tijuana Area }\end{array}$ & I & & \\
\hline 14 & $\begin{array}{l}\text { Chuto P., Iwu C. G amd Tengeh R. K. (2020) Non-Profit } \\
\text { Organisations and Socio-Economic Development in } \\
\text { South Africa: A literature Analysis }\end{array}$ & I & & \\
\hline 15 & $\begin{array}{l}\text { Conaty F. \& Robbins G. (2018). A stakeholder } \\
\text { Salience Perspective on Performance and Management } \\
\text { Control Systems in Non-Profit Organisations. }\end{array}$ & I & & \\
\hline 16 & $\begin{array}{l}\text { Cornell R. M., Johnson C. B., \& Schwartz W. C. (2013). } \\
\text { Influence of Leadership Positions on Internal Controls } \\
\text { and Reported Fraud in Religious Organizations }\end{array}$ & & I & \\
\hline 17 & $\begin{array}{l}\text { Daff L. \& Parker L. D. (2020) A Conceptual Model of } \\
\text { Accountants' Communication Inside not-for-profit } \\
\text { Organisations }\end{array}$ & & I & \\
\hline 18 & $\begin{array}{l}\text { Elson R. J., O'Callaghan S. \& Walker J. P. (2007). } \\
\text { Corporate Governance in Religious Organizations: A } \\
\text { Study of Current Practices in the Local Church. }\end{array}$ & & I & \\
\hline 19 & $\begin{array}{lcll}\text { Fang Q., Fisher K. R., \& Li B. (2019), Follower or } \\
\text { Challenger? } & \text { How } & \text { Chinese Non-governmental } \\
\text { Organizations } & \text { Manage } & \text { Accountability Requirements } \\
\end{array}$ & I & & \\
\hline
\end{tabular}




\section{I Macrothink}

\begin{tabular}{|c|c|c|c|c|}
\hline & from Funders & & & \\
\hline 20 & $\begin{array}{l}\text { Fonderer R., Holtzman M. P. \& Maccarrone E. (2003), } \\
\text { Internal Controls in the Talmud: The Jerusalem Temple }\end{array}$ & & l & \\
\hline 21 & $\begin{array}{l}\text { Friedland R. (2009), Institution, Practice and Ontology: } \\
\text { Toward a Religious Sociology }\end{array}$ & / & & \\
\hline 22 & $\begin{array}{l}\text { Geer B. W., Maher J. K. \& Cole M.T. (2008) Managing } \\
\text { Nonprofit Organizations: The Importance of } \\
\text { Transformational Leadership and Commitment to } \\
\text { Operating Standards for Nonprofit Accountability. }\end{array}$ & & & / \\
\hline 23 & $\begin{array}{l}\text { Givens R. J. (2012), The Study of the Relationship } \\
\text { Between Organizational Culture and Organizational } \\
\text { Performance in Non-Profit Religious Organizations }\end{array}$ & l & & \\
\hline 24 & $\begin{array}{l}\text { Gresakova E. (2020), The Impact of Time Management } \\
\text { of Finance of Slovak Non-Profit Organizations }\end{array}$ & & l & \\
\hline 25 & $\begin{array}{l}\text { Grimada G. \& Sacconi L. (2005), The Constitution of the } \\
\text { Not-For-Profit Organisation: Receprocal Conformity to } \\
\text { Morality }\end{array}$ & / & & \\
\hline 26 & $\begin{array}{l}\text { Hall M. \& O’Dwyer B. (2017). Accounting, } \\
\text { Non-governmental Organizations and Civil Society: The } \\
\text { Importance of Nonprofit Organizations to Understanding } \\
\text { Accounting, Organizations and Society }\end{array}$ & / & & \\
\hline 27 & $\begin{array}{l}\text { Irvine H. (2005). Balancing Money and Mission in a } \\
\text { Local Church Budget }\end{array}$ & / & & \\
\hline 28 & $\begin{array}{l}\text { Irvine H. (2007), Corporate Creep: An Institutional View } \\
\text { of Consultancies in a Non-Profit Organisation }\end{array}$ & / & & \\
\hline 29 & $\begin{array}{l}\text { Jamal A., Yaccob A., Bartikowski B. \& Slater S. (2019) } \\
\text { Motivations to Donate: Exploring the Role of } \\
\text { Religiousness in Charitable Donations, }\end{array}$ & / & & \\
\hline 30 & $\begin{array}{l}\text { Jayasinghe K., \& Soobaroyen T. (2009), Religious } \\
\text { "Spirit" and "Peoples' Perceptions of Accountability in } \\
\text { Hindu and Buddhist Religious Organizations }\end{array}$ & / & & \\
\hline 31 & $\begin{array}{l}\text { Kamaruddin M. I. H. \& Ramli N. M. 2017. A Case Study } \\
\text { of Internal Control Practices in Islamic Non-Profit } \\
\text { Organizations in Malaysia }\end{array}$ & & l & \\
\hline 32 & $\begin{array}{l}\text { Khorin, A. N., Brovkin A. V. and Potanina Y. M. (2018), } \\
\text { Management Economic Environment on Non-Profit } \\
\text { Organizations }\end{array}$ & / & & \\
\hline 33 & $\begin{array}{l}\text { Lightbody M. (2000), Storing and Shielding: Financial } \\
\text { Management Behaviour in a Church Organization }\end{array}$ & & & I \\
\hline
\end{tabular}




\begin{tabular}{|c|c|c|c|c|c|}
\hline 34 & $\begin{array}{l}\text { Lu Y., Jung J. H. \& Bauldry (2019), Explaining the } \\
\text { Cross-national Variation in the Relationship between } \\
\text { Religious Organization Membership and Civic } \\
\text { Organization Participation }\end{array}$ & / & & & \\
\hline 35 & $\begin{array}{l}\text { McMurray A. J., Pirola-Merlo A., Sarros J. C. \& Islam } \\
\text { M. M. (2010), Leadership, Climate, Psychological } \\
\text { Capital, Commitment and Wellbeing in a Non-Profit } \\
\text { Organization }\end{array}$ & & & & 1 \\
\hline 36 & $\begin{array}{l}\text { Moura L. F., de Lima E. P., Deschamps F., Van Aken E., } \\
\text { da Costa S. E., Treinta F. T. and Prado Cestari J. M. } \\
\text { (2019), Designing Performance Measurement Systems in } \\
\text { Nonprofit and Public Administration Organization. }\end{array}$ & & / & & \\
\hline 37 & $\begin{array}{l}\text { Moutchnik A. (2016), Environmental and Quality } \\
\text { Management Systems and Standards of Churches and } \\
\text { Religious Organizations }\end{array}$ & I & & & \\
\hline 38 & $\begin{array}{l}\text { Nawyn S. J. (2006), Faith, Ethnicity and Culture in } \\
\text { Refugee Resettlement }\end{array}$ & I & & & \\
\hline 39 & $\begin{array}{l}\text { Ortiz-Gomez M., Giorgi G., Molina-Sanchez H. \& } \\
\text { Ariza-Montes A. (2020), Development and Validation of } \\
\text { a Spanish Short Servant Leadership Survey among } \\
\text { Spanish Worlers in Religious Non-Profit Organizations }\end{array}$ & & & & I \\
\hline 40 & $\begin{array}{l}\text { Paiva I., \& Carvalho L. (2018). Accounting and } \\
\text { Management Practices in the Third Sector in Angola. }\end{array}$ & & & / & \\
\hline 41 & $\begin{array}{l}\text { Phipps K. A. and Burbach M. E. (2010), Strategic } \\
\text { Leadership in the Nonprofit Sector: Opportunities for } \\
\text { Research }\end{array}$ & & & & 1 \\
\hline 42 & $\begin{array}{l}\text { Radzi S. H. M. \& Noor R. M., (2012) “Tax Reporting for } \\
\text { Non-Profit Organizations (NPOs) in Malaysia }\end{array}$ & & & / & \\
\hline 43 & $\begin{array}{l}\text { Ramli N. M., Md Ali N. S. A. \& Muhammed N. A. } \\
\text { (2018), Integrated Reporting Based on Maqasid } \\
\text { Al-Shariah: A Proposed Framework for Islamic } \\
\text { Non-Profit Organizations }\end{array}$ & & & / & \\
\hline 44 & $\begin{array}{l}\text { Roslan N., Arshad R. \& Pauzi N. F. M. (2017). } \\
\text { Accountability and Governance Reporting by Non-Profit } \\
\text { Organizations. }\end{array}$ & & & / & \\
\hline 45 & $\begin{array}{l}\text { Saat N. F., Mohamed I. S., Zakaria N. B. \& Omar N. } \\
\text { (2013). Factors Determining Level of Internal Controls } \\
\text { Implementation Among Non Profit Organizations in } \\
\text { Malaysia. }\end{array}$ & & I & & \\
\hline
\end{tabular}




\section{MIMacrothink}

\begin{tabular}{|c|c|c|c|c|c|}
\hline 46 & $\begin{array}{l}\text { Said J., Mohamed A. Mohd-Sanusi Z. \& Syed-Yusuf S. } \\
\text { N. (2013) Financial Management Practices in Religious } \\
\text { Organizations: An Empirical Evidence of Mosque in } \\
\text { Malaysia }\end{array}$ & & / & & \\
\hline 47 & $\begin{array}{l}\text { Sapingi R., Nelson S. P. \& Obid S. N. S. } 2020 . \\
\text { Disclosure Practices and Efforts towards Proposing } \\
\text { I-ZKDI: A Case of Malaysian Religious Non-Profit }\end{array}$ & & & I & \\
\hline 48 & $\begin{array}{l}\text { Senses-Ozyurt (2015), Political } \\
\text { Environement and Management Culture as Determinants } \\
\text { of Nongovernmental /Nonprofit Organizations' } \\
\text { Performance }\end{array}$ & I & & & \\
\hline 49 & $\begin{array}{l}\text { Septianto F., Tjiptono F., Paramita W. \& Chiew T. M. } \\
\text { (2020) The Interactive Effects of Religiosity and } \\
\text { Recognition in Increasing Donation, }\end{array}$ & / & & & \\
\hline 50 & $\begin{array}{l}\text { Sharip S. M., Awang M \& Ismail R. } 2019 . \\
\text { onceptualizing the Impact of Leader-member Exchange } \\
\text { in Non-Profit and Religious Organisations: The Case of } \\
\text { Waqf Institutions in Malaysia. }\end{array}$ & & & & 1 \\
\hline 51 & $\begin{array}{l}\text { Slatten L. A., Bendickson J. S., Diamond M. \& } \\
\text { McDowell W. C. (2020), Staffing of Small Nonprofit } \\
\text { Organizations: A Model for Retaining }\end{array}$ & I & & & \\
\hline 52 & $\begin{array}{l}\text { Tanui P. J., Omare D. \& Bitange J. B. (2016) Internal } \\
\text { Control System for Financial Management in the } \\
\text { Church: A Case Study of Protestant Churches in Eldoret } \\
\text { Municipality Kenya }\end{array}$ & & I & & \\
\hline 53 & $\begin{array}{l}\text { Ventura M. \& Daniel S. J. (2010), Opportunities for } \\
\text { Fraud and Embezzlement in Religious Organizations: An } \\
\text { Exploratory Study }\end{array}$ & & I & & \\
\hline 54 & $\begin{array}{l}\text { Willems J., Boenigk S. \& Jegers M. (2014), Seven } \\
\text { Trade-offs in Measuring Nonprofit Performance and } \\
\text { Effectiveness }\end{array}$ & I & & & \\
\hline 55 & $\begin{array}{l}\text { Yaghi A. (2008). Leadership Values Influencing } \\
\text { Decision-Making: An Examination of Nine Islamic, } \\
\text { Hindu and Christian Nonprofit Institutions in the US }\end{array}$ & & & & I \\
\hline 56 & $\begin{array}{l}\text { Yasmin S. and Ghafran C. (2019), The Problematics of } \\
\text { Accountability: Internal Responses to External Pressures } \\
\text { in Exposed Organisations }\end{array}$ & I & & & \\
\hline 57 & $\begin{array}{l}\text { Yasmin S. \& Haniffa R. (2015), Acccountability and } \\
\text { Narative Disclosure by Muslim Charity Organisations in } \\
\text { the UK }\end{array}$ & & & I & \\
\hline 58 & $\begin{array}{l}\text { Yasmin S., Haniffa R., \& Hudaib M. (2014), } \\
\text { Communicated Accountability by Faith-Based Charity }\end{array}$ & & & I & \\
\hline
\end{tabular}




\begin{tabular}{|l|l|l|l|l|l|}
\hline Organisations & & & & \\
\hline 59 & $\begin{array}{l}\text { Yusop R., Mahmud R., Sabli N. Awang N. F. A. \& } \\
\text { Ghazali N. (2020). Sources of Funding for Private Tahfiz } \\
\text { Institutions in Kuala Selangor. }\end{array}$ & $/$ & & \\
\hline 60 & $\begin{array}{l}\text { Zainon S., Atan R. \& Wah Y. B. 2014. An Empirical } \\
\text { Study on the Determinants of Information Disclosure of } \\
\text { Malaysian Non-Profit Organizations. }\end{array}$ & / & & \\
\hline
\end{tabular}

\section{Copyrights}

Copyright for this article is retained by the author(s), with first publication rights granted to the journal.

This is an open-access article distributed under the terms and conditions of the Creative Commons Attribution license (http://creativecommons.org/licenses/by/4.0/) 